\title{
Bekkensmerter i svangerskapet et belastningssyndrom?
}

\author{
Eli Heiberg ${ }^{1}$ og Babill Stray-Pedersen ${ }^{2}$ \\ 1. Kompetansesenteret i fysioterapi, Postboks 7009 Majorstua, 0306 Oslo \\ 2. Kvinneklinikken, Rikshospitalet
}

\begin{abstract}
SAMMENDRAG
Smerter i bekkenregionen under graviditet representerer en epidemiologisk utfordring. Avgrensing overfor smerter i nedre del av rygg er uklar, likeledes patogenese og etiologi. Artikkelen setter søkelyset på medisinske og sosiokulturelle forhold knyttet til fenomenet. Noen nordiske prevalensdata bl.a. fra spørreskjemaundersøkelsen "Graviditet og arbeid" blir brukt som illustrasjon. Artikkelen konkluderer med forslag til videre forskning.
\end{abstract}

\section{ENGLISH SUMMARY}

Heiberg E, Stray-Pedersen B. Is pelvic pain during pregnancy a strain syndrome? Nor J Epidemiol 1997; 7 (1): 117-121.

Pain in the area of the pelvic girdle during pregnancy represents a challenge for epidemiologic research. Clinically the type of pain related to the pelvic girdle differs from that of low back pain, even if the two types of pain often occur together. Pathogenesis and etiology of pelvic pain in pregnancy is unclear. The article draws attention to biomedical as well as sociocultural factors associated with the phenomenon. Some Nordic prevalence data, among them the Norwegian questionnaire study "Pregnancy and Work" are used as illustrations. The article suggests areas for further research.

\section{INNLEDNING}

Bekken- og korsryggsmerter knyttet til svangerskap og fødsel er et stort helsemessig problem først og fremst for kvinnene selv, men også for barn, familie og samfunn. Tilstanden representerer et komplekst felt, med en tilsynelatende periodisk forekomst (1). De fleste nåtidige undersøkelser indikerer en prevalens mellom 20 og $50 \%$ avhengig av paritet. Høy grad av funksjonsnedsettelse angis hos 6-10\%. Tilstanden synes å øke i hyppighet og alvorlighetsgrad de siste tiår (2-8), men det er usikkert om økningen er reell. Den kan skyldes at gravide kvinner deltar mer, og således er blitt mer synlige, $i$ arbeids- og samfunnsliv.

Klinikk. Klinisk kjennetegnes bekkensmerter ved dyptsittende, tildels brått innsettende, stikkende smerter over symfysen og på begge sider av korsbenet. Et vedvarende smertebilde karakteriseres som dunkende og «varm» smerte. Væskestuvning og sterk palpasjonsømhet i det lille bekken ved vaginal- og rektal palpasjon er vanlige funn. Smertebildet kan minne om et muskellosjesyndrom (9). Vansker med å stige inn og ut, samt å snu seg i sengen rapporteres hyppig. Smerter ved vektbæring og vektoverføring som å stå og gå er andre hovedkjennetegn (10-11). Differensialdiagnostisk kan bekkensmerter være vanskelig å skille fra andre ikke utstrålende ryggsmerter. Ulike smerte- provoserende tester er prøvet ut i flere undersøkelser (6-7,12-14,15). Likeledes markering på smertetegninger for å skille eksempelvis mellom lumbale skiveprolaps og bekkensmerter $(6,16,17)$.

Nomenklaturen er lite spesifikk. Betegnelser og kriterier for svangerskapsrelaterte bekken- og korsryggsmerter varierer fra land til land, som på svensk «bakre- og eller fremre bäckensmärtor» eller engelsk «posterior pelvic pain» (13). Den vanligst brukte engelske betegnelsen er «back pain in pregnancy» $(8,18)$. Nederlandske forskere bruker «peri partum pelvic pain» (15) for det som på norsk nærmest vil svare til bekkenløsning eller bekkensmerter. En hyppig brukt dansk betegnelse har vært «bekkeninsufficiens» (14). Albert og Godskesen (15) har arbeidet for å finne klinisk hensiktsmessige avgrensninger av dette sekkebegrepet og lanserer i et kommende arbeid fire ulike underkategorier: symfyseløsning, både symfyse- og bekkenløsning (dvs. smerter over begge sacroiliacaledd ved leddprovosering), samt ensidige og dobbeltsidige sacroiliacasmerter. Betegnelsen «bekkenløsning» reserveres for pasienter som angir smerter både $\mathrm{i}$ symfyse og begge sacroiliacaledd etter ulike leddprovoserende tester.

I Norge nedsatte Lægeforeningen i 1990 et utvalg for å klargjøre de norske betegnelsene innen feltet. Det skilles mellom en «fysiologisk og en symptomgivende 
bekkenløsning», hvor sistnevnte foreslås som betegnelse for rygg- og bekkensmerter med gangforstyrrelser og positive provokasjonstester på bekkenets leddforbindelser. Denne betegnelsen er tidsbegrenset til seks måneder etter fødselen, plager som vedvarer etter denne tid kalles «bekkenleddsyndrom», eller på engelsk «pelvic girdle relaxation», alternativt «pelvic joint instability» (19).

\section{NORDISKE PREVALENSDATA}

De uklare betegnelser og mangelen på ensartede diagnostiske kriterier gjør det vanskelig å sammenligne de ulike undersøkelsene. De fleste undersøkelser viser at bekkensmerter såvel som korsryggsmerter $ø$ øer med økende antall barn, dog sterkere for bekkenenn for korsryggsmerter $(3,6,7)$. Andre ytre forhold som f.eks. sosioøkonomi, arbeidsbelastning, bevegelsesmønstre og livsstil er også dokumentert $(3,6,7,20)$.

I Sverige skilte Östgaard og medarbeidere (6) ut tre smerteområder, smerter i øvre og nedre del av rygg og smerte over korsben (sacroiliacaledd), og anga en samlet prevalensverdi for «back pain» på omkring $50 \%$. Mens smerte i ryggen enten avtok eller holdt seg konstant i løpet av svangerskapet, økte smertene over bekken og korsben. Kristiansson (12) fant noen år senere at bare ca. hver femte kvinne $(21,5 \%)$ hadde vondt $\mathrm{i}$ ryggen før graviditet. Om dette skyldtes en geografisk forskjell (Göteborg og Sundsvall), tilfeldige feil ved et meget mindre materiale $(n=200)$, eller ulik måte å stille innholdsmessig like spørsmål på, vites ikke. Han fant videre en økende prevalens av ryggsmerter i løpet av svangerskapet, fra 19,0\% i første til $49,1 \%$ i siste trimester. Ryggsmerter var delt inn etter lokalisasjon og omfattet ikke bare smerter knyttet til symfyse og sacroiliacaledd, men også smerter lumbalt og cervicothoracalt slik at bekkensmerter, forstått som smerter over symfyse- og korsben, var vanskelig å skille ut (12).

Vondt i ryggen før graviditet ses som en risikofaktor $(6,7)$. Östgaard (6) fant at for kvinner som ikke hadde hatt vondt i ryggen før svangerskapet var bekkensmerteinsidensen $27,7 \%$ mot $58,0 \%$ for dem som hadde hatt vondt. I den store danske undersøkelsen (18) er insidens for de ulike undergrupper ikke avklart ennå.

Det finnes få nyere norske undersøkelser. De fleste er utført på eksisterende pasientmaterialer som medlemmene $\mathrm{i}$ «Landsforeningen for kvinner med bekkenløsning» $(21,22)$, eller på pasienter som henvises til fysioterapi for svangerskapsrelaterte rygg-bekkenplager (23). Det er ukjent i hvilket omfang, og hvor lenge, slike smerter varer ved etter fødsel. Kogstad (24) undersøkte en normalpopulasjon ( $\mathrm{n}=1077$ ) i AustAgder i 1983-84 prospektivt. Alle kvinnene ble klinisk undersøkt med funksjons- og smerteprovoserende tester, og $23 \%$ ble funnet å ha hatt bekkenløsning i siste svangerskap. Et år etter fødselen hadde 3\% fortsatt symptomer.

\section{UNDERSØKELSEN: GRAVIDITET OG ARBEID}

Den største norske undersøkelsen om bekkensmerter (bekkenløsning) er spørreskjemaundersøkelsen "Graviditet og arbeid" fra Institutt for forebyggende medisin, UiO, 1989 (25). Målsetting for denne undersøkelsen var å kartlegge gravides arbeidsforhold i Norge. Alle som fødte i Norge i en seks ukers periode høsten 1989 fikk utdelt et spørreskjema mens de var på barselavdelingene. 5438 kvinner, $87,2 \%$ av dem som fødte i perioden, svarte. Et par spørsmål om bekken- og/eller korsryggsmerter var inkludert. Begge spørsmål hadde meget høy svarfrekvens ( $>90 \%$ ). Totalt oppga $42,4 \%$ av kvinnene at de hadde vært plaget av bekkensmerter, og $9,2 \%$ av dem anga at de hadde hatt store vansker med å utføre husarbeid (3). Tabell 1 viser materialet etter paritet og alder (26).

Vi ser en sterk positiv samvariasjon mellom bekkenmerter og paritet. Jo flere barn, jo mer plaget, men forskjellen er særlig markert mellom kvinner uten barn og kvinner med ett barn. Det er også interessant at de yngste kvinnene rapporterer mest plager.

Smertedebut ble funnet hos nær halvparten i 4-6 svangerskapsmåned, men såvidt mange som 16,6\% oppga debut allerede i første trimester, eller lenge før biomekaniske forandringer som økt vekt og endret tyngdeplassering forelå (26). Dette er i samsvar med andre studier $(6,12,16,18,23,27)$. En så tidlig debut kan peke i retning av økt sensibilitet hos visse kvinner overfor svangerskapets hormonelle forandringer $(12,27)$.

Det ble funnet positiv samvariasjon mellom bekkensmerter og vondt i korsryggen. Mens bekkensmerter klart synes knyttet til paritet, var andelen som svarte at de «bare» hadde hatt vondt i korsryggen tilnærmet den samme for første og flergangsfødende. Dette kan tyde på at bekkensmerter i svangerskapet må ses som en egen tilstand, og følgelig er noe annet enn korsryggsmerter (3).

I multiple regresjonsanalyser, etter korrigering for paritet og alder, viste følgende parametre klar sammenheng med bekkensmerter: Tung fysisk arbeidsbelastning, slik som daglig- stående gående arbeid, arbeid med overkroppen fremoverbøyd, vridninger og bøyninger mange ganger i timen, løft av 10-20 kg mer enn 5-10 ganger om dagen. Dette slo særlig ut i den yngste aldersgruppen 16-24 år $(3,20)$.

Det å røyke synes å henge sammen med utviklingen av bekkensmerter, mer enn korsryggsmerter selv om forskjellen ikke var statistisk signifikant for populasjonen som helhet. Alkohol derimot hadde en beskyttende effekt for utvikling av bekkensmerter. Både når det gjelder røyking og alkohol kan det tenkes at sammenhengene skyldes bakenforliggende forhold som man ikke har kunnet justere for $(3,20)$.

\section{Bekkensmerter og opplevelse av svangerskapet}

Det ble funnet en tydelig samvariasjon mellom bekkensmerter og totalopplevelse av svangerskapet. 
Tabell 1. Forekomst av bekkensmerter relatert til alder og antall barn. Prosent.

\begin{tabular}{|llccccc|}
\hline Alder & & $16-24$ år & $25-29$ år & $30-34$ år & $35-44$ år & Antall \\
\hline Paritet & 0 & 38,2 & 33,2 & 23,9 & 29,4 & 2512 \\
& 1 & 57,3 & 51,0 & 41,3 & 38,2 & 1677 \\
& 2 & 66,7 & 59,4 & 54,1 & 43,8 & 856 \\
& 3 & 85,7 & 66,7 & 53,6 & 52,4 & 193 \\
& $4+$ & & 42,9 & 56,3 & 52,6 & 77 \\
\hline Antall & & 1633 & 1948 & 1273 & 461 & 5315 \\
\hline
\end{tabular}

Tabell 2. Bekkensmerter og opplevelsen av svangerskapet.

\begin{tabular}{|lccc|}
\hline $\begin{array}{l}\text { Opplevelse av } \\
\text { svangerskapet }\end{array}$ & $\begin{array}{c}\text { Antall kvinner } \\
\text { som svarte }\end{array}$ & $\begin{array}{c}\text { Antall kvinner med } \\
\text { bekkensmerter }\end{array}$ & $\begin{array}{c}\text { Prosent med } \\
\text { bekkensmerter }\end{array}$ \\
\hline Mest med glede & 3161 & 1196 & 37,8 \\
Blandede følelser & 1498 & 793 & 50,3 \\
Håper aldri mer & 255 & 153 & 66,0 \\
Vet ikke & 127 & 66 & 52,9 \\
\hline Totalt & 5041 & 2168 & 43,0 \\
\hline
\end{tabular}

Tabell 2 viser hvordan kvinner med og uten bekkensmerter opplevde svangerskapet.

Tabellen viser at blant kvinner som ønsket aldri mer å oppleve en slik graviditet, hadde $2 / 3$ hatt bekkensmerter, mens forholdet var omvendt hos dem som husket graviditeten mest med glede. Selv om spørsmålet ikke ble stilt i relasjon til bekkensmerter, må det her kunne antas at bekkensmertene påvirker totalopplevelsen. Men fokusering av et personlig opplevelsesaspekt må ikke føre til at bekkensmerter kun ses som et privat anliggende. Bekkensmerter er både et privat og et offentlig fenomen. De angår ikke bare den enkelte kvinne og hennes nærmeste, men reflekterer også problemer med den sosiale struktur og de rammer graviditet i dag gis i vårt samfunn $(20,26)$.

\section{BEKKENSMERTER I ET SOSIALANTROPO- LOGISK PERSPEKTIV}

I hvilken grad bekkensmerter relatert til graviditet og fødsel er et universelt fenomen, eller et mer kulturbestemt syndrom, er lite studert. Tilstanden er klinisk kjent i afrikanske land (28). Situasjonen i asiatiske land er ukjent. Pakistanske kvinner i Norge forteller at slike smerter finnes ikke blant gravide i Pakistan, men at de får dem når de flytter til Norge.

Et så komplekst og muligens også kulturspesifikt fenomen som bekkenløsning, kan ikke forklares utelukkende biologisk. En sosialantropologisk vinkling kan dels være å studere bekkensmerter i et migrasjonsperspektiv hvor man søker innsikt i ulike kulturelle forestillinger knyttet til kropp og graviditet, og ser dette som lærte meningssammenhenger for såvel styring av handling som symbolske realiteter. Erkjen- nelsen av kroppen som vårt viktigste subjektive erfaringsfelt og uttrykksmiddel vil kunne være et ledd i å kunne se bekkensmerter som representasjon for en type livserfaringer, som kanskje ikke bare søker form, men også språk (1,29-32). Et kommunikasjons- og sosialiseringsperspektiv med fokus på innlæring av bevegelsesmønstre og aktivitetsvaner kan videre være en innfallsvinkel til forståelse av hvordan man i kulturen lærer seg å håndtere en vedvarende smertetilstand over tid (33). Det er kjent fra andre områder av medisinen at rapporterte symptom ikke nødvendigvis reflekterer en biologisk virkelighet. Kroppslige symptom er kulturelt modellert, og fastsettelsen av en eventuell diagnose er en mangesidig sosial prosess (29). Sosialisering inn i en kultur påvirker, ikke bare den allmenne forståelsen av et fenomen, men også hvordan dette betegnes, omtales og håndteres.

\section{EPIDEMIOLOGISKE UTFORDRINGER}

Smerter i korsryggen og smerter i bekkenet synes å ha ulikt etiologisk mønster. For å undersøke dette må betydningen av faktorer som paritet, mors alder, første menstruasjon, prevensjonsform, antall graviditeter og fødte barn, barnets fødselsvekt og kjønn, samt faktorer som røyking, yrke, ergonomisk arbeidsbelastning og grad av egenkontroll i livs- og arbeidssituasjonen undersøkes nøyere i store normalpopulasjoner (3,20-22). Dersom bekken- og korsryggsmerter viser seg å være avgrensbare kliniske enheter, er det behov for randomiserte, kontrollerte intervensjonsforsøk rettet mot såvel forebygging som behandling. Fysioterapeuters kliniske erfaringer bør systematiseres, dels gjennom en detaljert kartlegging av symptomatologi og anamnese, 
videre gjennom utvikling av standardiserte differensialdiagnostiske undersøkelsesprosedyrer, samt utprøving av ulike forebyggende og behandlende tiltak.

Svangerskapets hormonelle forandringer med økt væskeretensjon og strekkbarhet av ligamenter og bånd, biomekaniske forhold med endret vektbelastning, samt refererte smerter fra omkringliggende strukturer og korsrygg blir hyppig brukt som mulige forklaringsmodeller for bekkensmerter knyttet til graviditet og fødsel (5-19,21-24,27,35,36). Interessante funn er gjort mht. relaxinnivå og utvikling av bekkensmerter. Mac Lennan (27) og Kristiansson (35) fant samvariasjon mellom høye konsentrasjoner av serumrelaxin og symptomgivende bekkensmerter sent i graviditeten. Kristiansson undersøkte serumrelaxin ved fem ulike tidspunkt (fra 8-36 uke) i graviditeten, samt 12 uker etter fødselen og fant at serumrelaxin nådde et høydepunkt ved 12. svangerskapsuke. Han mener at høye verdier ved dette tidspunkt kan ses som en prediktor for utvikling av bekkensmerter. Dette står i kontrast til en dansk studie hvor man analyserte serumrelaxin i 33. svangerskapsuke, uten å kunne påvise noen sammenheng med bekkensmerter (36). En annen hypotese kan være at andre biologiske markører, som serumkonsentrasjonen av propeptider av type III procollagen (PIINP), progesteron og østrogen som påvirker fibroblastene i bekkenets ligamenter kan ha betydning for utvikling av bekkensmerter (35). Disse funn bør undersøkes på nytt og i større grupper. Et samarbeid med Norsk nyfødtkohorts Biobank vil kunne gi mulighet til gjennomføring av slike analyser.

Norsk nyfødtkohort åpner nye muligheter til kunnskap på dette ennå svært lite utforskede feltet. Ved de planlagte spørreskjemaundersøkelser kan man velge ut kvinner som rapporterer bekkenplager på forskjellige tidspunkt i svangerskapet og sammenligne dem med utvalgte kontroller. En slik tilnærming vil gi mulighet til å bekrefte eller avkrefte eksisterende hypoteser samt gi grunnlag for å utvikle nye problemstillinger.

\section{LITTERATUR}

1. Skylv G. Bækkenløsning - sygdom eller afvigelse? Stofskifte - Tidsskrift for Antropologi 1988; 18: 111-35.

2. Endresen E Heiberg. Bekkenløsning - en tilstand med mange navn og uklare kriterier. Tidsskr Nor Laegeforen 1995; 115: 3271-3.

3. Endresen E Heiberg. Pelvic pain and low back pain in pregnant women - an epidemiological study. Scand $J$ Rheumatol 1995; 24: 135-41.

4. Kogstad O. Bekkenløsning en kontroversiell diagnose. Tidsskr Nor Lageforen 1988; 108; 1115-9.

5. Kogstad O. Vond rygg etter fødsel. Hvem får det og hva er diagnosen? Tidsskr Nor Lageforen 1988; 108: 1120-2.

6. Östgaard HC, Andersson GBJ, Karlsson K. Prevalence of back pain in pregnancy. Spine 1988; 16: 549-52.

7. Berg G, Hammar M, Möller-Nielsen J, et al. Low back pain during pregnancy. Obstet Gynecol 1988; 71:71-5.

8. Mantle MJ, Greenwood RM, Currey HLF. Backache in pregnancy. I. Rheumathol Rehabil 1977; 16: 95-101.

9. Biørnstad N. Bekkenet på kryss og tvers. Cappelen akademiske, 1992.

10. Stuge B. Gange og instabilitet. Fysioterapeuten 1996; 5: 6-11.

11. Samuelsen G. Hoftens små utoverrotatorer undervurdert og misforstått? Fysioterapeuten 1996; 1: 18-22.

12. Kristiansson P, Svärsudd K, von Schoultz B. Back pain during pregnancy. A prospective study. Spine 1996; 21: 702-9.

13. Östgaard HC, Zetherström G, Roos-Hansson E, Svanberg B. Reduction of back pain and posterior pelvic pain in pregnancy. Spine 1994; 19: 894-900.

14. Wormslev M, Juul AM, Marques B, et al. Clinical examination of pelvic insufficiency during pregnancy. Scand J Rheumatol 1994; 23: 96-102.

15. Albert M, Godskesen M. The incidence of four well-defined conditions of pelvic joint pain during pregnancy (under bearbeidelse for British Journal of Obstetrics and Gynecology).

16. Mens JMA, Vleeming A, Stoeckart R, et al. Understanding peripartum pelvic pain. Implications of a patient survey. Spine 1996; 11: 1363-70.

17. Nielsen LL. Smertebilde ved bekkenløsningsplager og lumbalt skiveprolaps. Hovedfagsoppgave i fysioterapi, Det medisinske fakultet, Universitetet i Bergen, 1996.

18. Mac Evilly M, Buggy D. Back pain and pregnancy: A review. Pain 1996; 64: 405-14.

19. Kogstad O, Biørnstad N. Bekkenløsning patogenese/etiologi/definisjon/epidemiologi. Tidsskr Nor Lageforen 1990; 110: 2209-11.

20. Aarseth S.Platou. Å være i omstendigheter... Bekkenløsning i graviditet brukt som synliggjøring av kvinners arbeidsforhold og som trøbbelfenomen i arbeidslivet. Hovedoppgave i sosiologi, Universitetet i Oslo, 1992.

21. Saugstad LF. Persistent pelvic pain and pelvic joint instability. Eur J Obstet Gynecol Reprod Biol 1991; 41: 197-201. 
22. Saugstad LF. Is persistent pelvic pain and pelvic joint instability associated with early menarche and with oral contraceptives? Eur J Obstet Gynecol Reprod Biol 1991; 41: 203-6.

23. Hansen JH, Nielsen LL. Rygg- og bekkenrelaterte plager blant kvinner som følge av svangerskap og/eller fødsel. En spørreundersøkelse av kvinner med bekkenløsningsplager. Rapport til Fond til etter- og videreutdanning av fysioterapeuter, Norske Fysioterapeuters Forbund, 1995.

24. Kogstad O. Bekkenløsning. En kontroversiell diagnose. Tidsskr Nor Loegeforen 1988; 108: 1115-9.

25. Wergeland E, Strand K, Endresen E Heiberg. Gravid i Norge ved inngangen til nittiårene. Graviditet og arbeid. Rapport 1. Institutt for forebyggende medisin, Universitetet i Oslo, 1991.

26. Heiberg E, Aarseth SP. Epidemiology of pelvic pain and low back pain in pregnant women. I: Vleeming A, Stoeckart R, red. Movement, stability and low back pain - an interdisciplinary approach. Churchill Livingstone, Edinburgh, 1997.

27. Mac Lennan AH. The role of the hormone relaxin in human reproduction and pelvic girdle relaxation. Scand $J$ Rheumatol 1991 (suppl. 88): 7-15.

28. Bjørklund K. Gynekolog med mangeårig erfaring fra arbeid i Afrika, overlege ved Kvinneklinikken Gävle sjukhus, Sverige, personlig meddelelse, høsten 1996.

29. Lock M, Scheper-Hughes N. A critical-interpretive approach in medical anthropology: Rituals and routines of discipline and dissent. I: Johnson T, Sargent C, red. Medical Anthropology, Contemporary Theory and Method. Praeger Publishers, New York, 1990.

30. Engelsrud G. Kvinner i bevegelse - mellom lyst og lengsel. Senter for kvinneforskning. Arbeidsnotat 5/95, Universitetet i Oslo, 1995.

31. Leseth A. Bevegelseskultur. Et antropologisk perspektiv på kroppslig bevegelse i Dar-es-Salaam, Tanzania. Hovedoppgave i sosialantropologi, Inst. og museum for antropologi, Universitetet i Oslo, 1995.

32. Broch-Due V, Rudie I. Carved flesh/cast selves: An introduction. I: Broch-Due V, Bleie T, red. Carved Flesh/Cast Sleves. Berg Press, Oxford, 1993.

33. Lilleaas U-B. Når forskjellen blir synlig - kvinner med kroniske muskelsmerter i et kjønnsrolleperspektiv. Senter for kvinneforskning, Arbeidsnotat 8/95, Universitetet i Oslo.

34. Östgaard HC, Andersson GBJ, Schultz AB, Miller JAA. Influence of some biomechanical factors on low back pain in pregnancy. Spine 1993; 18: 61-5.

35. Kristiansson P, Svärsudd K, von Schoultz B. Serum relaxin, symphyseal pain and back pain during pregnancy. Am J Obstet Gynecol (in press).

36. Albert H, Godskesen M, Westergaard JG, Chard T, Gunn L. Circulating levels of relaxin are normal in pregnant women with pelvic pain. Eur J Obstet Gynecol Reprod Biol (in press). 